\title{
Root Coverage using Double Papilla with Connective Tissue Graft: A 13-month Report of a Successful Case
}

\author{
${ }^{1}$ Sathyanarayana Sunil, ${ }^{2}$ Harsha M Babu
}

\begin{abstract}
Introduction: Several techniques have been used to achieve root coverage and augment attached gingiva, including laterally positioned flaps, coronally positioned flaps, free gingival grafts, guided tissue regeneration, and connective tissue grafting. The decision of using a pedicle procedure or free tissue grafts is based on availability of the adjacent donor site and the width and depth of the defect site.
\end{abstract}

Case report: In this report, a young female patient reported with a deep and wide recession defect (Miller's class I) in the upper right central incisor with minimal keratinized gingival width. As the adjacent papillae were wide and showed good donor tissue and augmentation of width and thickness of keratinized gingiva were intended, double-papilla flap and connective tissue graft was performed. The 13-month postoperative showed Cairo's root coverage esthetic score of 6 , satisfying the patient's esthetic needs.

Conclusion: The root coverage achieved was structurally and functionally stable at 13-month follow-up satisfying the patient's esthetic needs.

Clinical significance: This procedure seems to be a promising treatment option for deep-wide gingival recessions for root coverage and increasing the thickness and width of keratinized gingiva.

Keywords: Connective tissue graft, Double-papilla flap, Root coverage.

How to cite this article: Sunil S, Babu HM. Root Coverage using Double Papilla with Connective Tissue Graft: A 13-month Report of a Successful Case. J Health Sci Res 2017; 8(2):77-79.

Source of support: Nil

Conflict of interest: None

\section{INTRODUCTION}

Various mucogingival procedures have been used to achieve root coverage and augment attached gingiva, including laterally positioned flaps, semilunar coronally positioned flaps, free gingival grafts, as well as

\footnotetext{
${ }^{1}$ Associate Professor, ${ }^{2}$ Reader

1,2Department of Periodontics, Dayananda Sagar College of Dental Sciences, Bengaluru, Karnataka, India

Corresponding Author: Harsha M Babu, Reader, Department of Periodontics, Dayananda Sagar College of Dental Sciences Bengaluru, Karnataka, India, Phone: +918026663654, e-mail: harshamb@yahoo.com
}

guided tissue regeneration (GTR) and connective tissue grafting. ${ }^{1-6}$ Treatment of gingival recession defects with pedicle flaps results in a long junctional epithelial attachment, ${ }^{7}$ but shows good root coverage and keratinized tissue augmentation as the pedicles have their own blood supply. Placement of a free gingival graft results in regeneration of cementum, bone, and connective tissue attachment. ${ }^{8}$ New bone and new cementum formation are observed with GTR. ${ }^{9}$ However, in a recent review, Danesh-Meyer and Wikesjö ${ }^{10}$ mentioned that GTR does not provide additional clinical benefits over connective tissue grafting or advanced flap procedures and can be hazardous than helpful for the clinician in controlling primary wound closure, membrane exposure, space maintenance, and unacceptable foreign-body reactions. Furthermore, connective tissue grafts over gingival recession defects have shown periodontal regeneration. ${ }^{11-13}$

Double-papilla laterally positioned flaps for the treatment of gingival recession were first described by Wainberg in 1964 and refined by Cohen and Ross in $1968 .{ }^{14}$

In this case of gingival recession, we wanted to make use of the advantages of double papilla and connective tissue as the young female patient presented with a deep-wide recession in the esthetically critical upper anterior region. We used the connective tissue graft underneath the double papilla to successfully achieve the required outcome.

\section{CASE REPORT}

A 29-year-old female patient reported to the dental clinic with a long appearance of upper front teeth. On examination, multiple gingival recessions were seen in the upper anterior teeth. The patient was highly concerned about the long appearing upper right central incisor, which had Miller's class I recession defect. The recession defect was deep-wide recession, measuring $7 \mathrm{~mm}$ deep and $5 \mathrm{~mm}$ wide, with lack of keratinized gingiva (Fig. 1). Patient insisted treatment only for this particular tooth.

As the adjacent papillae were wide, double-papilla flap was planned and increase in the width and thickness of the keratinized gingiva was intended, connective tissue graft was utilized.

\section{SURGICAL PROCEDURE}

The recipient area was prepared with adequate anesthesia using $2 \%$ lignocaine $\mathrm{HCl}$ containing 1:80,000 adrenaline. 


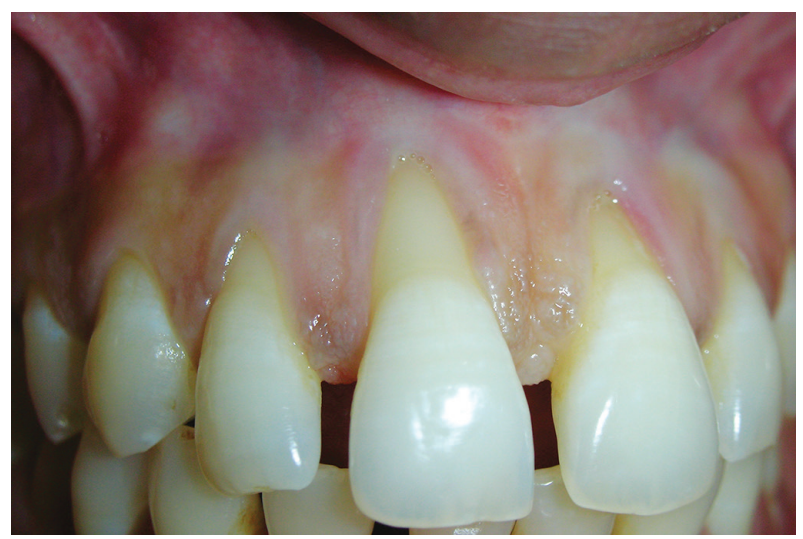

Fig. 1: Preoperative picture showing $7 \mathrm{~mm}$ deep and $5 \mathrm{~mm}$ wide gingival recession on upper right central incisor

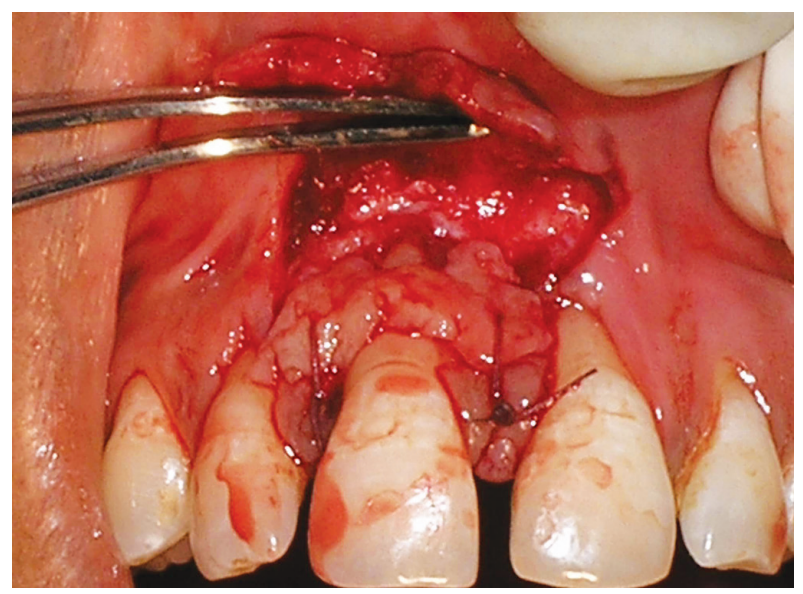

Fig. 3: Connective tissue graft sutured over the recession site

A trapezoidal flap was designed using three different types of incisions:

1. Primary incisions were made in mesial and distal directions at the base of the interdental papilla of upper right central incisor, preserving the interdental papilla.

2. A sulcular incision was made connecting the primary incisions.

3. Two apically diverging vertical incisions were made starting at the end of each of the primary incisions, extending apically into the alveolar mucosa.

A full thickness flap was raised till the mucogingival junction beyond which a sharp dissection was made to raise a combined full-partial thickness flap (Fig. 2). The flap was extended well beyond the mucogingival junction to relieve the tension when placed over the connective tissue graft. The root was thoroughly planed and convexities of the root were reduced. At this stage, the desired dimension of connective tissue graft was procured from the patient's palate using the technique suggested by Bruno ${ }^{15}$ and sutured over the recipient recession site (Fig. 3). The mesial and the distal pedicles were sutured together in the midline, placed over the connective tissue graft, and secured to the interdental papilla. Vertical releasing incisions were sutured (Fig. 4)

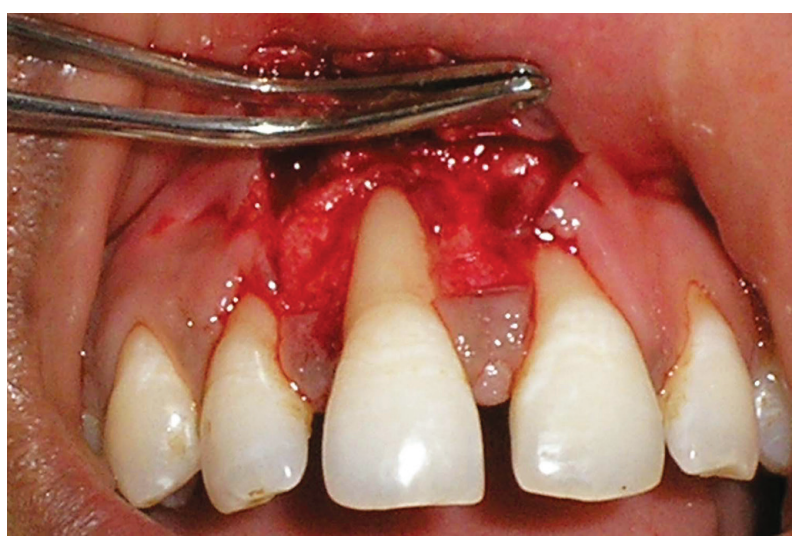

Fig. 2: Combined full-partial thickness double-papilla flap reflected

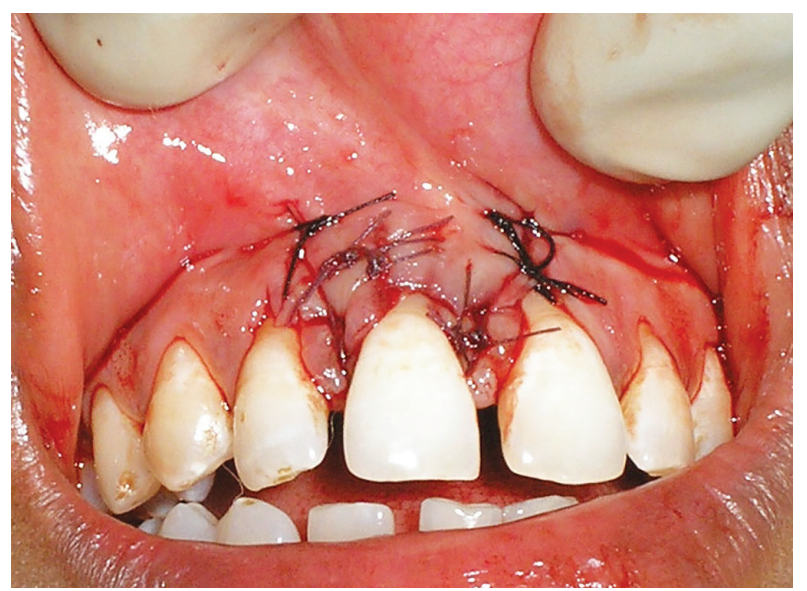

Fig. 4: Double-papilla flaps sutured over the connective tissue graft

and periodontal pack was placed. The patient was recalled for suture removal after giving postoperative instructions and medication. The sutures were removed on the 12th day, which showed good augmentation of keratinized gingiva and root coverage (Fig. 5). The patient was told not to brush in that area for 1 week and to maintain hygiene using chlorhexidine mouthwash. The 13th month follow-up showed Cairo's root coverage esthetic score (RES) value ${ }^{16}$ of 6 with good periodontal health with increase in thickness and width of keratinized tissue and root coverage of up to $5 \mathrm{~mm}$ (Fig. 6), satisfying the patient's esthetic needs.

\section{DISCUSSION}

In recent times, with the proper case selection and the appropriate technique from the various treatment options available, root coverage has become more predictable. Although multiple gingival recessions were observed in this case, the patient was mainly concerned about treatment for the upper right central incisor. A double-papilla flap was chosen as the interproximal papillae adjacent to the recession were sufficiently wide, attached gingiva on an approximating tooth was insufficient to allow for 


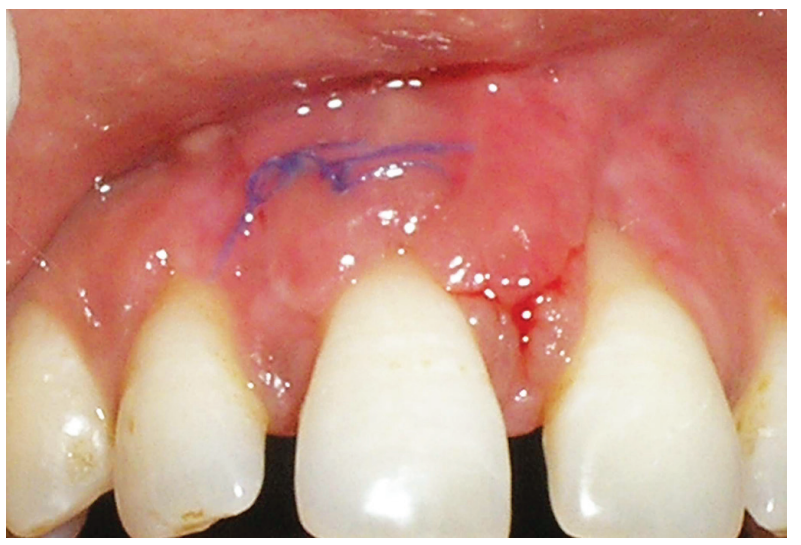

Fig. 5: Day 12 postoperative picture at the time of suture removal

a laterally positioned flap, and periodontal pockets were not present. ${ }^{14}$ Since the recession was wide and deep and augmentation of keratinized gingiva was intended, connective tissue grafting was combined in the present case. In this report, Cairo's RES scoring system ${ }^{16}$ was used for an objective way of measuring the treatment outcome with RES value of 6 .

Borghetti and Louise ${ }^{17}$ have shown predictability of a connective tissue graft under a double-papillae flap. Our case showed a successful result similar to the study conducted by Harris ${ }^{18}$ in which double-pedicle flap with connective tissue graft produced a larger increase in keratinized tissue and greater root coverage when recessions exceeded $5 \mathrm{~mm}$. Thus, the double-papilla flap with connective tissue graft might be considered a useful technique in the treatment of deep-wide gingival recession defects.

\section{CONCLUSION}

The root coverage achieved was structurally, esthetically, and functionally stable at 13 months follow-up. Patient was extremely happy with the treatment outcome and the procedure seems to be a promising treatment option for root coverage and augmentation of keratinized gingiva.

\section{REFERENCES}

1. Miller PD Jr. Root coverage using the free soft tissue autograft following citric acid application. III. A successful and predictable procedure in areas of deep-wide recession. Int J Perio Rest Dent 1985;5(2):14-37.

2. de Waal H, Kon S, Ruben MP. The laterally positioned flap. Dent Clin North Am 1988 Apr;32(2):267-285.

3. Thompson BK, Meyer R, Singh GB, Mitchell W. Desensitization of exposed root surfaces using a semilunar coronally positioned flap. Gen Dent 2000 Jan-Feb;48(1):68-71.

4. Pini Prato G, Clauser C, Cortellini P, Tinti C, Vincenzi G, Pagliaro U. Guided tissue regeneration versus mucogingival surgery in the treatment of human buccal recessions. A 4-year follow-up study. J Periodontol 1996 Nov;67(11): $1216-1223$.

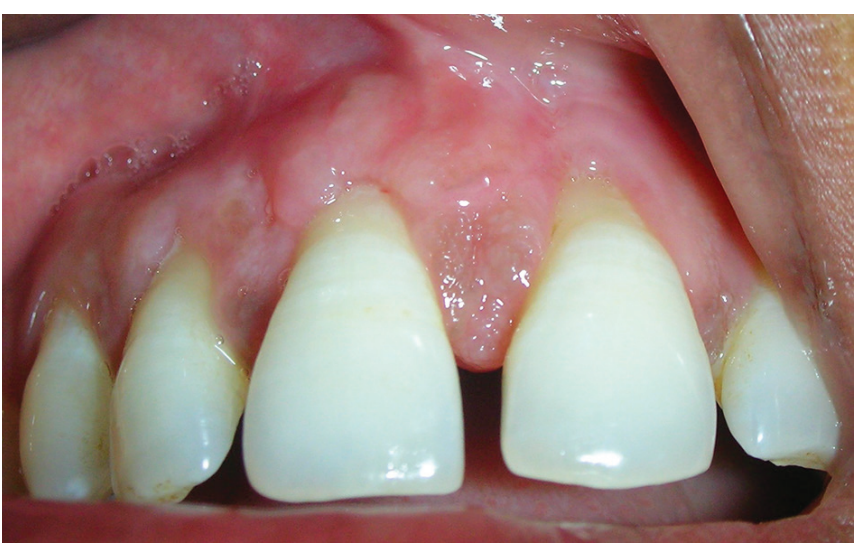

Fig. 6: Postoperative picture of 13 months follow-up showing 5 $\mathrm{mm}$ recession coverage

5. Tözüm TF, Dini FM. Treatment of adjacent gingival recessions with subepithelial connective tissue grafts and the modified tunnel technique. Quintessence Int 2003 Jan;34(1):7-13.

6. Wang HL, Kimble K, Eber R. Use of bone grafts for the enhancement of a GTR-based root coverage procedure: a pilot case study. Int J Perio Rest Dent 2002 Apr;22(2):119-127.

7. Caffesse RG, KonS, CastelliWA, NasjletiCE. Revascularization following the lateral sliding flap procedure. J Periodontol 1984 Jun;55(6):352-358.

8. Pasquinelli KL. The histology of new attachment utilizing a thick autogenous soft tissue graft in an area of deep recession: a case report. Int J Periodontics Restorative Dent 1995 Jun;15(3):248-257.

9. Cortellini P, Clauser C, Pini Prato GP. Histologic assessment of new attachment following the treatment of a human buccal recession by means of guided tissue regeneration procedure. J Periodontol 1993 May;64(5):387-391.

10. Danesh-Meyer MJ, Wikesjö UM. Gingival recession defects and guided tissue regeneration: a review. J Periodontal Res 2001 Dec;36(6):341-354

11. Harris RJ. Successful root coverage: a human histologic evaluation of a case. Int J Periodontics Restorative Dent 1999 Oct;19(5):439-447.

12. Bruno JF, Bowers GM. Histology of a human biopsy section following the placement of a subepithelial connective tissue graft. Int J Periodontics Restorative Dent 2000 May/ Jun;20(3):225-231.

13. Allen AL. Use of the supraperiosteal envelope in soft tissue grafting for root coverage. II. Clinical results. Int J Periodontics Restorative Dent 1994 Aug;14(4):302-315.

14. Cohen DW, Ross SE. The double papillae repositioned flap in periodontal therapy. J Periodontol 1968 Mar;39(2):65-70.

15. Bruno JF. Connective tissue graft technique assuring wide root coverage. Int J Periodontics Restorative Dent 1994 Apr;14(2):127-137.

16. Cairo F, Rotundo R, Miller PD, Pini Prato GP. Root coverage esthetic score: a system to evaluate the esthetic outcome of the treatment of gingival recession through evaluation of clinical cases. J Periodontol 2009 Apr;80(4):705-710.

17. Borghetti A, Louise F. Controlled clinical evaluation of the subpedicle connective tissue graft for the coverage of gingival recession. J Periodontol 1994 Dec;65(12):1107-1112.

18. Harris RJ. Connective tissue grafts combined with either double pedicle grafts or coronally positioned pedicle grafts: results of 266 consecutively treated defects in 200 patients. Int J Perio Rest Dent 2002 Oct;22(5):463-471. 